\title{
Impact of Pretreatment and Drying Methods on Quality Attributes of Onion Shreds
}

\author{
Nihar R. Sahoo ${ }^{1}$, Lalit M. Bal ${ }^{*}$, Uma S. Pal ${ }^{1}$ and Dipika Sahoo ${ }^{3}$ \\ ${ }^{1}$ Department of Agricultural Processing and Food Engineering, Orissa University of Agriculture and \\ Technology, Bhubaneswar, Odisha-751003, India \\ ${ }^{2}$ Post Harvest Process and Food Engineering, College of Agriculture, Jawaharlal Nehru Agricultural \\ University, Tikamgarh, Madhya Pradesh-472001, India \\ ${ }^{3}$ Department of Horticulture, College of Agriculture, Bhawanipatna, Orissa University of \\ Agriculture and Technology, Bhubaneswar, Odisha-751003, India
}

Received: January 14, 2014

Accepted: December 10, 2014

\begin{abstract}
Summary
Experiments were conducted on dry untreated onion shreds ( $2 \mathrm{~mm}$ thickness) or treated with salt (5\% solution) and potassium metabisulphite $(0.5 \%$ solution) in convective drier at $50{ }^{\circ} \mathrm{C}((46 \pm 4) \%$ relative humidity $(\mathrm{RH})), 55^{\circ} \mathrm{C}((35 \pm 4) \% \mathrm{RH}), 60^{\circ} \mathrm{C}((28 \pm 4) \% \mathrm{RH})$ and $65{ }^{\circ} \mathrm{C}((20 \pm 4) \% \mathrm{RH})$, heat pump-assisted convective drier at $35^{\circ} \mathrm{C}((32 \pm 2) \% \mathrm{RH}), 40{ }^{\circ} \mathrm{C}$ $((26 \pm 2) \% \mathrm{RH}), 45^{\circ} \mathrm{C}((19 \pm 2) \% \mathrm{RH})$ and $50{ }^{\circ} \mathrm{C}((15 \pm 2) \% \mathrm{RH})$ and microwave-assisted convective drier at four microwave power levels, i.e. 120, 240, 360 and $480 \mathrm{~W}$. The quality parameters of the dried onion shreds, namely rehydration ratio, colour difference, pyruvic and ascorbic acid contents and sensory scores were evaluated. The quality of dehydrated onion shreds was observed to be comparatively better when treated in heat pump drier at $50{ }^{\circ} \mathrm{C}$, followed by that in microwave-assisted convective drier at $240 \mathrm{~W}$ and $50{ }^{\circ} \mathrm{C}$, and last in convective drier at $60^{\circ} \mathrm{C}$. The onion shreds pretreated with potassium metabisulphite retained better colour of the dried product irrespective of drying methods. Therefore, heat pump drying may be recommended as one of the best drying methods for onion shreds, because it maintains the final product quality, which has practical importance for the food industry.
\end{abstract}

Key words: pretreatment, hot air drying, heat pump drying, microwave-assisted convective drying, onion

\section{Introduction}

Onion (Allium cepa L.) is one of the most popular vegetables in the world, and finds widespread usage in both fresh and dried forms. It contains vitamin B and traces of vitamin C, iron and calcium. The most distinctive characteristic of onion is its pungency, which is due to allyl-propyl disulphide. Onions compared with other fresh vegetables have relatively high heat energy value, intermediate protein content and are rich in calcium and riboflavin. Dried onions are of considerable importance in world trade and are made in several forms: flaked, minced, chopped and powdered. It is also used as a flavour additive in a wide variety of food formulations (1).

The existing hot air drying methods for onions are costly and cause considerable shrinkage due to cellular collapse following the loss of water, poor rehydration characteristics of the dehydrated product and undesirable changes in colour, texture, flavour and nutritive value. New and innovative techniques like microwave-assisted (2) and heat pump-assisted convective drying $(3,4)$, 
which increase the drying rates and enhance dried onion quality, are receiving considerable attention. Microwave drying is now gaining popularity because of its inherent advantages over conventional heating such as reduced drying time and lower energy consumption of biological material without quality loss $(5,6)$. Heat pump-assisted convective drying is known to be more energy efficient than traditional convective drying operations. Most of the research studies infer that the heat pump-assisted convective drying offers products of better quality with reduced energy consumption (7).

Agricultural products and foodstuffs are commonly pretreated prior to industrial drying to speed up the drying process and preserve the quality of the product. Lewicki et al. (8) found that both variety and pretreatment affect the course and rate of drying. Drying time of onion could be reduced to less than half by introducing an hour of osmotic dehydration in a salt solution, which also preserves its colour (9). The drying rates could be improved by pretreatments like blanching and dipping the fruits in chemicals before drying (10-13). Pretreatments reduced the drying time and yielded a good quality dried product. Potassium metabisulphite is most commonly and commercially used for pretreatment, because it prevents enzymatic browning of fruits and increases the permeability of water (12).

Farag et al. (14) subjected sliced onions to various treatments in order to inhibit enzymatic browning. All applied treatments reduced ascorbic acid by $50 \%$ due to leaching and volatile sulphur compounds more than 30 $\%$. Raj et al. (15) observed significant differences in the retention of moisture, reducing sugars, non-reducing sugars, ascorbic acid, acidity, rehydration ratio and overall acceptability of dried onion rings pretreated with potassium metabisulphite ( $2.5 \mathrm{~g} / \mathrm{L}$ of solution) during storage. Tsamo et al. (16) stated that osmotically dehydrated onion slices in sugar $(600 \mathrm{~g} / \mathrm{L})$, salt $(300 \mathrm{~g} / \mathrm{L})$ or mixed salt and sugar (45:15 by mass) solutions for $15 \mathrm{~min}$ followed by convective drying with air at $60{ }^{\circ} \mathrm{C}$ increased the drying rate and moisture diffusitivity. Baroni and Hubinger (17) also studied air drying of fresh and osmotically pretreated onion slices for $60 \mathrm{~min}$ at 40,50 and $60^{\circ} \mathrm{C}$ and observed faster drying rate of samples soaked in $10 \% \mathrm{NaCl}$ solution. Recently, Bebartta et al. (18) suggested drying the 2-mm onion slices under fluidized bed at $60{ }^{\circ} \mathrm{C}$ and air velocity of $4 \mathrm{~m} / \mathrm{s}$ to obtain a better quality product with savings in drying time.

Onion is a heat-sensitive crop requiring suitable dehydration process to preserve its organoleptic characteristics. Novel dehydration techniques and pretreatments may be used for onion drying to obtain a product with minimal change in physical, biochemical, nutritional and sensory attributes of high consumer acceptance. Literature review revealed that the research on onion dehydration is unsystematic. There is a need to study the feasibility of drying onion with different drying methods and pretreatments to get the best quality. Keeping this in view, the present work has been undertaken to study the effects of pretreatments and different drying methods on the quality of dehydrated onion shreds. Also, comparative quality evaluation of dehydrated onion shreds obtained by different drying methods has been undertaken.

\section{Materials and Methods}

\section{Drying equipment}

Three laboratory-scale driers, namely hot air drier, heat pump-assisted convective drier and microwave-assisted convective drier were used for thin layer drying of onion shreds. The laboratory atmospheric batch-type tray drier (model TD-12; Indian Instruments and Chemicals, Ambala, India) consisted of an insulated drying chamber with trays, fan, electrical heater and digital temperature indicator-cum-controller to maintain the desired drying air temperature with $\pm 0.1^{\circ} \mathrm{C}$ accuracy.

The heat pump-assisted convective drier (Fig. 1), which was developed for laboratory drying experiments, discussed elsewhere (19), consists of heat pump unit (evaporator, compressor, condenser and expansion device) and drying chamber with trays. The drier was operated with R22 (DuPont ${ }^{\mathrm{TM}}$ Freon ${ }^{\circledR} 22$, DuPont Fluorochemicals, Wilmington, DE, USA) refrigerant and fitted with a $1-\mathrm{kW}$ compressor to operate the heat pump. A fin heater is also connected in the air path for additional heating (19).

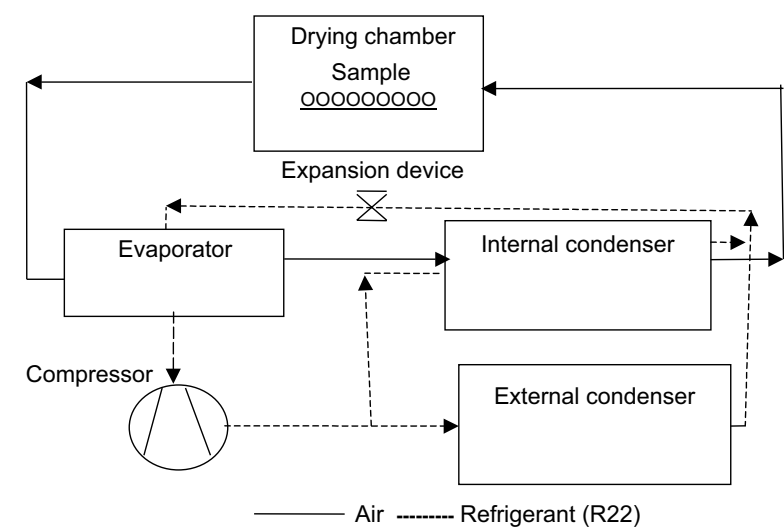

Fig. 1. Schematic diagram of heat pump drier configuration with air and refrigerant circuit

The microwave-assisted convective drier was developed using a domestic microwave oven (LG Intellowave 3850002GO31A, LG Electronics, New Delhi, India). The back of the oven just above the turntable was cut open and coupled with the air heating unit to supply air at desired temperature (20). In all cases the air flow was diagonal to the material on the trays and the air velocity was 2 $\mathrm{m} / \mathrm{s}$ (Fig. 2).

\section{Raw material and sample preparation}

Onion, cv. Nasik Red, purchased from a local vegetable market, Bhubaneswar, India, was used for the experiments. The bulbs were graded on the basis of size, and those of 50-60 $\mathrm{mm}$ in diameter without visible damage were chosen for the experiments. The selected onion samples were cleaned, hand peeled and trimmed. These were sliced to 2-mm thick shreds using stainless steel knives and the shreds were separated to single pieces of length of 15 to $20 \mathrm{~mm}$. During slicing and shredding of onion, care was taken to avoid any drip loss. 


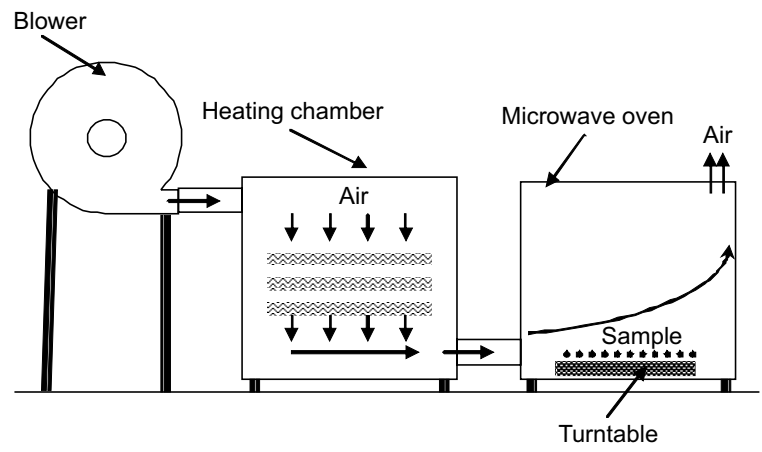

Fig. 2. Schematic diagram of microwave-assisted convective drier

Onion shreds were divided into three lots, one lot was pretreated with $5 \%$ salt solution for $1 \mathrm{~h}$ with a constant solid-to-liquid ratio of $1: 4$ at room temperature $\left((30 \pm 1){ }^{\circ} \mathrm{C}\right)$, second lot was sulphited with $0.5 \%$ potassium metabisulphite (Central Drug House (P) Ltd., New Delhi, India) solution for $10 \mathrm{~min}$ and the third lot, without any pretreatment, was used as control (21). The water adhering to the surfaces of strained pretreated samples was removed with tissue paper prior to drying.

\section{Drying procedure}

About $4.2 \mathrm{~kg} / \mathrm{m}^{2}$ of untreated and pretreated onion shreds were spread uniformly in thin layers on the drying trays $\left(0.6 \times 0.8 \mathrm{~m}^{2}\right)$ for all the drying methods. The details of drying methods used for the study were as follows: (i) hot air drying at four air temperatures with corresponding relative humidity $(\mathrm{RH})$, viz. $50{ }^{\circ} \mathrm{C}(46 \% \mathrm{RH}), 55^{\circ} \mathrm{C}(35$ $\% \mathrm{RH}), 60{ }^{\circ} \mathrm{C}(28 \% \mathrm{RH})$ and $65{ }^{\circ} \mathrm{C}(20 \% \mathrm{RH})$; (ii) heat pump drying at four air temperatures with corresponding relative humidity, viz. $35{ }^{\circ} \mathrm{C}(32 \% \mathrm{RH}), 40{ }^{\circ} \mathrm{C}(26 \%$ $\mathrm{RH}), 45^{\circ} \mathrm{C}(19 \% \mathrm{RH})$ and $50{ }^{\circ} \mathrm{C}(15 \% \mathrm{RH})$; and (iii) microwave-assisted convective drying at four microwave power levels, i.e. $120,240,360$ and $480 \mathrm{~W}$ at $50{ }^{\circ} \mathrm{C}$.

All experiments were done at a constant air velocity of $2 \mathrm{~m} / \mathrm{s}$. The changes in the mass of the samples were measured at predetermined time intervals until constant mass was attained. Dehydrated shreds were packed quickly in polyethylene bags and stored in desiccators for further analysis.

\section{Quality evaluation of dried onion shreds}

\section{Moisture content}

The moisture content of the onion samples was measured gravimetrically by hot air oven drying method (22). A mass of 20-30 g of sliced samples (in three replications) was kept in the oven at $70{ }^{\circ} \mathrm{C}$ for $72 \mathrm{~h}$. Average initial moisture content of control onion samples was found to be $(730 \pm 7) \%$ (on dry basis). The reproducibility of the initial moisture content measurements was within the range of $\pm 5 \%$.

\section{Rehydration}

The rehydration characteristics of the dehydrated onion shreds were studied in terms of the rehydration ratio. Rehydration ratios of dehydrated onion shreds were de- termined by the methods suggested by Ranganna (23). The time of soaking was initially standardized by soaking $2 \mathrm{~g}$ of dehydrated onion slices in $100 \mathrm{~mL}$ of distilled water maintained at $(31 \pm 1){ }^{\circ} \mathrm{C}$. After every $15 \mathrm{~min}$, the sample was taken out and put in Büchner funnel which was fitted with a coarsely porous Whatman No. 4 (GE Healthcare Life Sciences, Little Chalfont, UK) filter paper. A gentle suction was applied to drain the excess water. Any trace of surface moisture was then removed with the help of a tissue paper and then the samples were weighed. The process was continued until a constant reading was obtained. It was observed that the mass of sample was equilibrated after $3 \mathrm{~h}$, which was subsequently used for studies on rehydration quality of onion samples. All samples were weighed under the same conditions. All measurements were carried out in triplicate, and the rehydration ratio was expressed as the ratio of mass after rehydration to the mass before the rehydration of the sample:

$$
\text { Rehydration ratio }=m_{\mathrm{r}} / m_{\mathrm{d}}
$$

where $m_{\mathrm{r}}$ is the drained mass (in $\mathrm{g}$ ) of the rehydrated sample, and $m_{\mathrm{d}}$ is the mass (in $\mathrm{g}$ ) of the dry sample used for rehydration.

\section{Ascorbic acid content}

Ascorbic acid content of the fresh and dehydrated onion shreds was estimated using titration method suggested by Ranganna (23) based on the reduction of 2,6-dichlorophenol indophenol dye (Sigma-Aldrich, St. Louis, MO, USA) by ascorbic acid and was expressed in mg per $100 \mathrm{~g}$ of fresh mass.

\section{Pungency}

Pungency was measured by determining the pyruvic acid concentration using the method of Schwimmer and Weston (24). Onion pungency is caused by a number of volatile sulphur compounds. These compounds are produced when the onion cell is mechanically disrupted, bringing the enzyme alliinase present in the cell cytoplasm into contact with the flavour precursors, $S$-alk(en) yl-L-cysteine sulphoxides. In addition to producing volatile sulphur compounds, the enzymatic breakdown of the $S$-alk(en)yl-L-cysteine sulphoxides also produces stoichiometric amounts of ammonia and pyruvic acid. The amount of pyruvic acid generated enzymatically upon homogenization of onion in a blender is thus a good measure of the action of the alliinase on the flavour precursors and has been shown to be correlated with perceived onion pungency (24). This enzymatically produced pyruvic acid is the commonly accepted measure of onion pungency. It is, however, only an indicator of pungency as pyruvate and does not directly contribute to onion flavour. In order to determine the amount of enzymatically derived pyruvic acid, a correction for the endogenous, non-enzymatically derived pyruvic acid should be made. The amount of enzymatically produced pyruvic acid was estimated by the modified Schwimmer and Weston method as recommend by Anthon and Barret (25). For pyruvic acid determination, $10 \mathrm{~mL}$ of distilled water were added to $10 \mathrm{~g}$ of dehydrated onion sample and homogenised manually with a mortar and pestle. The homogenate was allowed to stand for $10 \mathrm{~min}$ at room temperature, fol- 
lowed by filtering with filter paper. A volume of $2.5 \mathrm{~mL}$ of clarified onion filtrate was taken, $1.0 \mathrm{~mL}$ of water and 1.0 $\mathrm{mL}$ of $0.25 \mathrm{~g} / \mathrm{L}$ of 2,4-dinitrophenylhydrazine (DNPH) in $1 \mathrm{M} \mathrm{HCl}$ were added and the samples were incubated in a water bath at $37{ }^{\circ} \mathrm{C}$ for $10 \mathrm{~min}$. After removal from the water bath, $1.0 \mathrm{~mL}$ of $1.5 \mathrm{M} \mathrm{NaOH}$ was added. The absorbance of the developed colour was measured at $515 \mathrm{~nm}$ in a spectrophotometer (model 106, Systronics, Ahmedabad, Gujarat, India).

\section{Colour evaluation}

Surface colour of dried onion shreds was evaluated using a HunterLab colourimeter (ColourFlex, Hunter Associates Laboratory, Inc., Reston, VA, USA) equipped with a $12-\mathrm{mm}$ measuring head. Colour was measured using the CIE $L^{*}, a^{*}, b^{*}$ scale and illuminant D65. The instrument was calibrated with black and white reference tiles through the tristimulus values $\mathrm{X}, \mathrm{Y}$ and $\mathrm{Z}$, taking as standard values those of the white background ( $X=79.01$; $\mathrm{Y}=83.96 ; \mathrm{Z}=86.76$ ) tile. Colour values were expressed as $L$ (whiteness or brightness/darkness), a (redness/greenness) and $b$ (yellowness/blueness) at any time. Since the dried onion shreds did not cover the entire surface area, they were scanned at three different locations to determine the average $L^{*}, a^{*}$ and $b^{*}$ values during the measurements. Numerical values of $L^{*}, a^{*}$ and $b^{*}$ were considered for the evaluation of colour modification of the product. In addition, the colour difference $(\Delta E)$ was calculated from the Hunter $L^{*}, a^{*}, b^{*}$ scale and used to describe the colour change during drying (26):

$$
\Delta E=\sqrt{\left(L_{0}^{*}-L_{\mathrm{t}}^{*}\right)^{2}+\left(a_{0}^{*}-a_{\mathrm{t}}^{*}\right)^{2}+\left(b_{0}^{*}-b_{\mathrm{t}}^{*}\right)^{2}}
$$

where $L_{0}^{*}, a_{0}^{*}$ and $b_{0}^{*}$ are the initial colour measurements of fresh samples, and $L_{\mathrm{t}}^{*}, a_{\mathrm{t}}^{*}$ and $b_{\mathrm{t}}^{*}$ are the colour measurements at prespecified time.

\section{Sensory analysis}

A semi-trained panel of 15 members evaluated the colour, appearance, texture, flavour, taste and overall acceptability of the products on a nine-point hedonic scale. The panellists were unaware of the project objectives. Samples were coded with three-digit random numbers and then served. Panelists were provided with a glass of water, and were instructed to rinse and swallow water between samples. They were given written instructions and asked to evaluate the overall acceptability of the products based on their appearance, texture, taste and colour using a nine-point hedonic scale ( $1=$ dislike extremely to $9=$ like extremely) (27).

\section{Statistical analysis}

The obtained results were subjected to analysis of variance (ANOVA) using SPSS v. 10.0 software (IBM Corporation, Armonk, NY, USA). The mean values obtained from each set were compared using Duncan's multiple range test based on a complete randomized design (at 0.05 confidence level).

\section{Results and Discussion}

\section{Effects of drying methods on the quality of dried onion shreds}

\section{Hot air-dried samples}

The quality parameters of hot air-dried onion shreds are given in Table 1. Air temperature used for drying was found to have significant effect on quality parameters of dried onion shreds. The rehydration ratio of the sample dried at $50{ }^{\circ} \mathrm{C}$ was $4.76 \pm 0.52$ and it decreased $(8 \%)$ to $4.09 \pm 0.42$ when the sample was dried at $65^{\circ} \mathrm{C}$. The rehydration ratio of onion shreds dried at $65{ }^{\circ} \mathrm{C}$ was less $(11.5 \%)$ than that of dried at $60^{\circ} \mathrm{C}$, which might be caused by hardening of the surface due to fast initial drying at higher temperature. There was no significant variation in the rehydration ratio of samples dried at 50 to $60{ }^{\circ} \mathrm{C}$. Similar results were observed by Maskan $(28,29)$ for banana and kiwi fruit.

Product colour is an important quality parameter that needs to be maintained during onion drying. The colour change increased from $12.04 \pm 1.21$ to $17.14 \pm 1.32$ with increasing air temperature used for drying from 50 to 65 ${ }^{\circ} \mathrm{C}$ (Table 1). The changes of colour could be attributed to the Maillard browning reactions that took place during the drying process (30). Temperature of $65{ }^{\circ} \mathrm{C}$ used for drying adversely influenced the colour of dried onion. Browning was observed to be more severe at the end of the drying period, when the moisture level was low and less evaporative cooling took place, which caused the increase in product temperature. It is evident that drying at higher temperature resulted in greater colour change. Hence browning could be minimized by reducing the drying temperature. Arslan and Özcan (31) reported that the drying temperature exerted a pronounced effect on the colour changes of shredded onion. Kumar et al. (32) also mentioned that enzymatic browning reactions were accelerated by increasing the temperature, which led to discoloration. In the present experiment a significant change in colour was observed only at $65^{\circ} \mathrm{C}$, which confirmed the report by Lewicki et al. (33) that browning of onion dried at the temperature higher than $60{ }^{\circ} \mathrm{C}$ took place mainly in the final stages of the process.

Table 1. Quality parameters of onion shreds dried at different drying air temperatures in hot air drier

\begin{tabular}{|c|c|c|c|c|c|}
\hline \multirow{2}{*}{$\begin{array}{c}\begin{array}{c}\text { Drying air } \\
\text { temperature }\end{array} \\
\frac{{ }^{\circ} \mathrm{C}}{}\end{array}$} & \multirow{2}{*}{ DR } & \multirow{2}{*}{ RR } & \multirow{2}{*}{$\Delta E$} & \multirow{2}{*}{$\frac{b(\text { pyruvic acid })}{\mu \mathrm{mol} / \mathrm{g}}$} & \multirow{2}{*}{$\frac{w(\text { ascorbic acid })}{\mathrm{mg} / 100 \mathrm{~g}}$} \\
\hline & & & & & \\
\hline 55 & $6.46 \pm 0.12$ & $4.71 \pm 0.35$ & $13.29 \pm 1.02$ & $49.65 \pm 2.30$ & $20.66 \pm 1.42$ \\
\hline 60 & $6.55 \pm 0.21$ & $4.62 \pm 0.46$ & $13.53 \pm 0.91$ & $48.93 \pm 1.59$ & $19.95 \pm 1.56$ \\
\hline
\end{tabular}

$\mathrm{DR}=$ dehydration ratio, $\mathrm{RR}=$ rehydration ratio, $\Delta E=$ colour difference 
Pyruvic and ascorbic acid contents decreased with the increase in drying air temperature and the rate of decrease was observed to be significantly greater at $65{ }^{\circ} \mathrm{C}$ (Table 1). Pyruvic acid amount decreased from (50.77 \pm 2.02$)$ to $(43.14 \pm 1.68) \mu \mathrm{mol} / \mathrm{g}$ (by $15 \%$ ), while that of ascorbic acid decreased from $(21.00 \pm 1.51)$ to $(17.82 \pm 1.26) \mathrm{mg}$ per $100 \mathrm{~g}$ (by $15.14 \%$ ) with the increase of temperature from 50 to $65^{\circ} \mathrm{C}$. Adam et al. (30) also reported the loss of pyruvic and ascorbic acids during drying at higher temperature. This is because most of the volatile flavour components have low boiling points and ascorbic acid is known to be temperature dependent.

The mean sensory score of hot air-dried onion shreds is given in Table 2 . The scores of all the sensory attributes except colour did not vary significantly with the drying temperature range under study. It was observed that there was no significant variation in sensory scores of samples dried at 50,55 and $60{ }^{\circ} \mathrm{C}$, whereas colour, flavour and overall acceptability of samples dried at $65^{\circ} \mathrm{C}$ varied significantly. Due to shorter drying time requirement and non-significant reduction in quality parameters, it is recommended to dry onion shreds in hot air drier at $60^{\circ} \mathrm{C}$ to obtain a finished product of acceptable quality.

Samples dried in heat pump-assisted convective drier

The quality parameters of onion shreds dried in heat pump-assisted convective drier are given in Table 3. Drying temperature had a significant effect on rehydration ratio, colour change, pyruvic and ascorbic acid contents, whereas dehydration ratio did not vary significantly. It was found that dehydration and rehydration ratios increased by 33.92 and $19.9 \%$, respectively, with the increase in air temperature from 35 to $50{ }^{\circ} \mathrm{C}$. This might be due to lower equilibrium moisture content of the samples dried at higher temperature and lower relative humidity. Besides, drying at up to $50{ }^{\circ} \mathrm{C}$ does not affect the cell structure, which promotes more water uptake during rehydration.

The surface colour change was found to be highest $(10.25 \pm 0.65)$ at $35^{\circ} \mathrm{C}$, which is probably due to longer drying time of the sample. However, there was not much variation in the colour change of samples dried at 40 to 50 ${ }^{\circ} \mathrm{C}$ in heat pump-assisted convective drier.

In the fresh onion, the L-ascorbic and pyruvic acid contents amounted to $27.21 \mathrm{mg}$ per $100 \mathrm{~g}$ and $66.30 \mu \mathrm{mol} / \mathrm{g}$, respectively. Drying temperature of $35^{\circ} \mathrm{C}$ adversely influenced the retention of pyruvic and ascorbic acids. These were observed to be lower in the samples dried in a heat pump-assisted convective drier. Sarsavadia (34) reported that during longer drying period the product was exposed to the atmospheric oxygen, which has an adverse effect on some quality aspects like reduction in ascorbic acid in the final product. Adam et al. (30) also found that longer drying resulted in the decrease of pyruvate and ascorbic acid contents. The retention of pyruvic and ascorbic acids was relatively higher in samples dried at 45 and $50{ }^{\circ} \mathrm{C}$. Since there was no significant variation in these values and samples dried at $50{ }^{\circ} \mathrm{C}$ took less time, it may be recommended to dry samples at $50{ }^{\circ} \mathrm{C}$ in heat pump-assisted convective drier.

Sensory evaluation of final products is shown in Table 4 . The colour and overall acceptability of onion shreds dried at $50{ }^{\circ} \mathrm{C}$ was better, while the colour, flavour and overall acceptability score varied significantly in the samples dried at $35{ }^{\circ} \mathrm{C}$. This might be due to longer drying time that affected the product quality.

\section{Microwave-assisted convective air dried sample}

The quality parameters of onion shreds dried in microwave-assisted convective drier are given in Table 5 . The dehydration ratio increased from $6.34 \pm 0.12$ to $6.71 \pm 0.34$

Table 2. Mean sensory scores of onion shreds dried in hot air drier at different temperatures

\begin{tabular}{ccccc}
\hline $\begin{array}{c}\text { Drying air } \\
\text { temperature }\end{array}$ & Colour & Texture & Flavour & $\begin{array}{c}\text { Overall } \\
\text { Tacceptability }\end{array}$ \\
\hline${ }^{\circ} \mathrm{C}$ & $8.71 \pm 0.24$ & $8.53 \pm 0.62$ & $8.84 \pm 0.45$ & $8.62 \pm 0.64$ \\
50 & $7.64 \pm 0.35$ & $8.14 \pm 0.54$ & $7.21 \pm 0.75$ & $7.12 \pm 0.48$ \\
65 & $7.43 \pm 0.26$ & $7.91 \pm 0.53$ & $7.26 \pm 0.36$ & $7.07 \pm 0.35$ \\
65 & $7.32 \pm 0.42$ & $8.02 \pm 0.46$ & $7.13 \pm 0.48$ & $7.04 \pm 0.43$ \\
\hline
\end{tabular}

Table 3. Quality parameters of onion shreds dried at different temperatures in heat pump drier

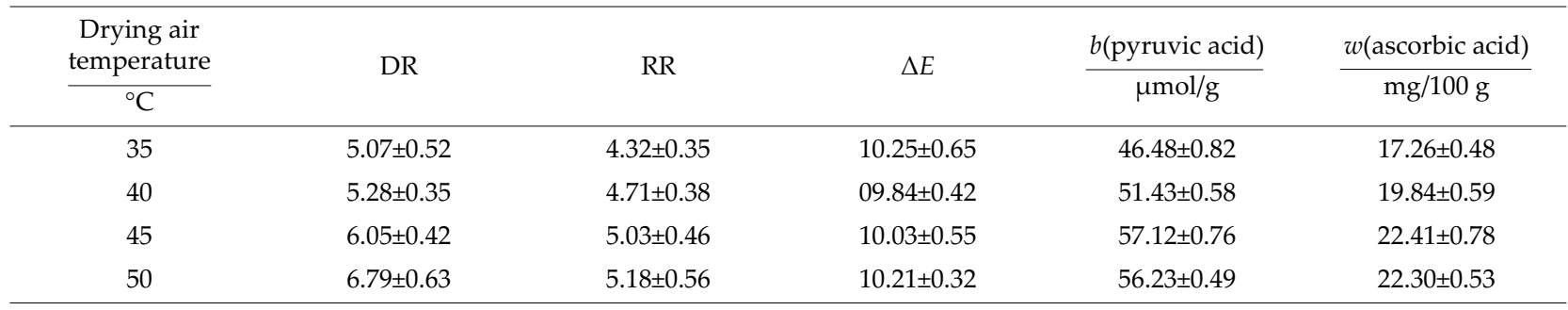

$\mathrm{DR}=$ dehydration ratio, $\mathrm{RR}=$ rehydration ratio, $\Delta E=$ colour difference 
Table 4. Mean sensory scores of onion shreds dried in heat pump drier at different temperatures

\begin{tabular}{cccccc}
\hline $\begin{array}{c}\text { Drying air } \\
\text { temperature }\end{array}$ & Colour & Texture & Flavour & Taste & $\begin{array}{c}\text { Overall } \\
\text { acceptability }\end{array}$ \\
\hline${ }^{\circ} \mathrm{C}$ & $8.72 \pm 0.32$ & $8.54 \pm 0.23$ & $8.82 \pm 0.33$ & $8.64 \pm 0.49$ & $8.82 \pm 0.57$ \\
35 & $7.51 \pm 0.45$ & $7.91 \pm 0.41$ & $7.04 \pm 0.56$ & $7.42 \pm 0.52$ & $7.13 \pm 0.75$ \\
40 & $7.93 \pm 0.36$ & $8.15 \pm 0.69$ & $7.32 \pm 0.48$ & $7.31 \pm 0.46$ & $7.42 \pm 0.46$ \\
45 & $8.14 \pm 0.47$ & $8.26 \pm 0.72$ & $7.61 \pm 0.34$ & $7.13 \pm 0.31$ & $7.64 \pm 0.43$ \\
50 & $8.26 \pm 0.43$ & $8.45 \pm 0.46$ & $7.53 \pm 0.21$ & $7.24 \pm 0.39$ & $7.72 \pm 0.34$ \\
\hline
\end{tabular}

Table 5. Quality parameters of onion shreds dried at different microwave (MW) power levels at $50{ }^{\circ} \mathrm{C}$ in microwave-assisted convective drier

\begin{tabular}{|c|c|c|c|c|c|}
\hline$\frac{\text { MW power level }}{W}$ & DR & $\mathrm{RR}$ & $\Delta E$ & $\frac{b \text { (pyruvic acid) }}{\mu \mathrm{mol} / \mathrm{g}}$ & $\frac{w \text { (ascorbic acid) }}{\mathrm{mg} / 100 \mathrm{~g}}$ \\
\hline 120 & $6.34 \pm 0.12$ & $4.98 \pm 0.42$ & $14.98 \pm 0.37$ & $52.06 \pm 0.72$ & $20.20 \pm 0.45$ \\
\hline 240 & $6.45 \pm 0.25$ & $5.12 \pm 0.21$ & $16.00 \pm 0.59$ & $50.24 \pm 0.76$ & $19.85 \pm 0.72$ \\
\hline 360 & $6.62 \pm 0.14$ & $5.03 \pm 0.36$ & $20.16 \pm 0.61$ & $45.56 \pm 0.81$ & $18.26 \pm 0.51$ \\
\hline 480 & $6.71 \pm 0.34$ & $4.76 \pm 0.45$ & $25.91 \pm 0.42$ & $39.13 \pm 0.59$ & $16.51 \pm 0.56$ \\
\hline
\end{tabular}

$\mathrm{DR}=$ dehydration ratio, $\mathrm{RR}=$ rehydration ratio, $\Delta E=$ colour difference

with the increase in microwave power level and drying temperature. The rehydration ratio was observed to be lower $(4.76 \pm 0.45)$ at higher microwave power $(480 \mathrm{~W})$ and drying temperature $\left(50^{\circ} \mathrm{C}\right)$ compared to $5.12 \pm 0.21$ at 210 $\mathrm{W}$ and $50{ }^{\circ} \mathrm{C}$. This may be due to rapid drying. However, at lower microwave power and drying temperature, the difference was not significant. Maskan $(28,29)$ also reported similar results for banana and kiwi fruit.

Microwave drying at higher power level (480 W) showed greater colour change $(25.91 \pm 0.42)$ with higher redness on the edges of the samples (Table 5), which affected the total colour change value. Browning of dried onion in convective drying assisted with microwave is also reported by Lewicki et al. (33). The colour change at higher microwave power level was observed to be greater, which might be caused by the fact that the energy delivered by the microwaves increased the temperature of the product above the temperature of the drying air. Since the non-enzymatic browning is temperature dependent, higher microwave power caused more browning (35).

Pyruvic and ascorbic acid contents decreased by 24.84 and $18.27 \%$, respectively, with the increase of microwave power level from 120 to $480 \mathrm{~W}$ at $50{ }^{\circ} \mathrm{C}$. Yong- sawatdigul and Gunasekaran (36) also reported quality loss of foods during drying with the continuous application of microwave energy. It was observed that drying of onion shreds at microwave power levels of 120 and $240 \mathrm{~W}$ could retain substantial amount of quality attributes as compared to other combinations.

Sensory scores were observed to decrease with the increase in microwave power level (Table 6). As there was no significant variation in sensory scores of samples dried at 120 and $240 \mathrm{~W}$, and drying at $240 \mathrm{~W}$ took less time, it may be recommended to dry onion shreds at $240 \mathrm{~W}$ and $50{ }^{\circ} \mathrm{C}$ in microwave-assisted hot air drier.

\section{Effects of pretreatments on quality of dried onion shreds}

It was observed that dehydration and rehydration ratios of salt-treated samples were lower and of sulphited samples higher compared to the untreated ones (Table 7). Although a change in all the quality characteristics was observed among the treated and untreated samples, the changes did not show definite pattern of significance level. However, pyruvic and ascorbic acid contents did not

Table 6. Mean sensory scores of onion shreds dried in microwave-assisted convective drier at different microwave (MW) power levels and $50{ }^{\circ} \mathrm{C}$

\begin{tabular}{cccccc}
\hline MW power level & Colour & Texture & Flavour & Taste & $\begin{array}{c}\text { Overall } \\
\text { acceptability }\end{array}$ \\
\cline { 1 - 5 } Fresh sample & $8.72 \pm 0.53$ & $8.52 \pm 0.51$ & $8.82 \pm 0.32$ & $8.64 \pm 0.22$ & $8.82 \pm 0.24$ \\
120 & $7.04 \pm 0.42$ & $7.92 \pm 0.47$ & $7.35 \pm 0.35$ & $7.32 \pm 0.41$ & $7.34 \pm 0.43$ \\
240 & $6.82 \pm 0.46$ & $8.03 \pm 0.36$ & $7.24 \pm 0.47$ & $7.31 \pm 0.35$ & $7.42 \pm 0.37$ \\
360 & $6.23 \pm 0.34$ & $7.84 \pm 0.35$ & $6.95 \pm 0.21$ & $7.16 \pm 0.19$ & $6.91 \pm 0.44$ \\
480 & $5.16 \pm 0.25$ & $7.52 \pm 0.41$ & $6.22 \pm 0.33$ & $6.82 \pm 0.38$ & $6.32 \pm 0.51$ \\
\hline
\end{tabular}


Table 7. Effects of pretreatments on the quality of onion shreds dried under different drying conditions

\begin{tabular}{|c|c|c|c|c|c|}
\hline & DR & $\mathrm{RR}$ & $\Delta E$ & $\frac{b(\text { pyruvic acid) }}{\mu \mathrm{mol} / \mathrm{g}}$ & $\frac{w(\text { ascorbic acid) }}{\mathrm{mg} / 100 \mathrm{~g}}$ \\
\hline \multicolumn{6}{|c|}{ Hot air drying at $60^{\circ} \mathrm{C}$} \\
\hline Untreated & $6.55 \pm 0.53$ & $4.82 \pm 0.13$ & $13.53 \pm 0.37$ & $48.93 \pm 0.77$ & $19.95 \pm 0.53$ \\
\hline Salt-treated & $6.13 \pm 0.59$ & $4.56 \pm 0.25$ & $12.76 \pm 0.49$ & $45.28 \pm 0.78$ & $17.23 \pm 0.58$ \\
\hline Sulphited & $7.43 \pm 0.37$ & $5.01 \pm 0.39$ & $9.80 \pm 0.38$ & $46.52 \pm 0.69$ & $18.45 \pm 0.75$ \\
\hline \multicolumn{6}{|c|}{ Heat pump drying at $50^{\circ} \mathrm{C}$} \\
\hline Untreated & $6.79 \pm 0.19$ & $5.18 \pm 0.37$ & $10.21 \pm 0.53$ & $56.23 \pm 0.19$ & $22.30 \pm 0.29$ \\
\hline Salt-treated & $6.20 \pm 0.27$ & $4.86 \pm 0.22$ & $9.77 \pm 0.35$ & $53.98 \pm 0.37$ & $21.18 \pm 0.23$ \\
\hline Sulphited & $7.54 \pm 0.23$ & $5.25 \pm 0.38$ & $8.93 \pm 0.37$ & $54.66 \pm 0.49$ & $21.65 \pm 0.33$ \\
\hline \multicolumn{6}{|c|}{ Microwave-assisted drying at $240 \mathrm{~W}$ and $50^{\circ} \mathrm{C}$} \\
\hline Untreated & $6.45 \pm 0.23$ & $5.12 \pm 0.26$ & $16.00 \pm 0.83$ & $50.24 \pm 0.63$ & $19.85 \pm 0.53$ \\
\hline Salt-treated & $6.34 \pm 0.28$ & $4.98 \pm 0.22$ & $13.70 \pm 0.72$ & $48.45 \pm 0.72$ & $19.81 \pm 0.55$ \\
\hline Sulphited & $6.62 \pm 0.31$ & $5.20 \pm 0.37$ & $11.73 \pm 0.68$ & $48.82 \pm 0.86$ & $19.99 \pm 0.61$ \\
\hline
\end{tabular}

$\mathrm{DR}=$ dehydration ratio, $\mathrm{RR}=$ rehydration ratio, $\Delta E=$ colour difference

Table 8. Effects of pretreatments on mean sensory scores of onion shreds dried under different drying conditions

\begin{tabular}{|c|c|c|c|c|c|}
\hline & Colour & Texture & Flavour & Taste & $\begin{array}{c}\text { Overall } \\
\text { acceptability }\end{array}$ \\
\hline Fresh sample & $8.71 \pm 0.31$ & $8.51 \pm 0.25$ & $8.86 \pm 0.19$ & $8.62 \pm 0.13$ & $8.82 \pm 0.23$ \\
\hline \multicolumn{6}{|c|}{ Hot air drying at $60^{\circ} \mathrm{C}$} \\
\hline Untreated & $7.33 \pm 0.15$ & $8.02 \pm 0.13$ & $7.16 \pm 0.23$ & $7.04 \pm 0.57$ & $7.34 \pm 0.27$ \\
\hline Salt-treated & $7.43 \pm 0.35$ & $7.84 \pm 0.22$ & $6.74 \pm 0.26$ & $6.82 \pm 0.37$ & $7.13 \pm 0.19$ \\
\hline Sulphited & $7.72 \pm 0.29$ & $7.73 \pm 0.39$ & $6.82 \pm 0.31$ & $6.84 \pm 0.15$ & $7.52 \pm 0.34$ \\
\hline \multicolumn{6}{|c|}{ Heat pump drying at $50^{\circ} \mathrm{C}$} \\
\hline Untreated & $8.21 \pm 0.17$ & $8.41 \pm 0.19$ & $7.51 \pm 0.32$ & $7.21 \pm 0.37$ & $7.73 \pm 0.51$ \\
\hline Salt-treated & $8.34 \pm 0.45$ & $8.28 \pm 0.12$ & $7.14 \pm 0.35$ & $6.92 \pm 0.23$ & $7.51 \pm 0.36$ \\
\hline Sulphited & $8.53 \pm 0.39$ & $8.13 \pm 0.23$ & $7.26 \pm 0.25$ & $7.04 \pm 0.16$ & $8.02 \pm 0.34$ \\
\hline \multicolumn{6}{|c|}{ Microwave-assisted drying at $240 \mathrm{~W}$ and $50^{\circ} \mathrm{C}$} \\
\hline Untreated & $6.82 \pm 0.31$ & $8.04 \pm 0.15$ & $7.25 \pm 0.25$ & $7.36 \pm 0.13$ & $7.42 \pm 0.29$ \\
\hline Salt-treated & $6.91 \pm 0.12$ & $7.86 \pm 0.17$ & $6.91 \pm 0.33$ & $7.25 \pm 0.16$ & $7.24 \pm 0.27$ \\
\hline Sulphited & $7.14 \pm 0.34$ & $7.64 \pm 0.24$ & $7.03 \pm 0.34$ & $7.11 \pm 0.21$ & $7.63 \pm 0.34$ \\
\hline
\end{tabular}

follow a specific trend with pretreatment, which might be due to leaching loss during the treatment with a solution. The colour change was lower in sulphited samples, giving a light coloured product, probably due to the leaching of reducing sugar during initial pretreatment, which was responsible for the browning reaction (8). The colour change was observed to be higher in salt-treated samples. Although the texture of the untreated sample was well maintained, colour change was observed to be highest. Therefore, samples pretreated with potassium metabisulphite were found to be the best in terms of less colour change and higher rehydration ratio even though the contents of pyruvic and ascorbic acids were observed to be higher in the untreated samples.

Among the sensory parameters, the colour score was observed to be higher in sulphited samples, whereas the texture, flavour and taste scores were higher in untreated samples under all the drying conditions (Table 8). As colour is an important parameter for judging the quality of dehydrated onion, sulphiting of the samples is recommended to maintain the colour of dried product.

\section{Conclusions}

Temperatures of $60{ }^{\circ} \mathrm{C}$ in hot air drier and $50{ }^{\circ} \mathrm{C}$ in heat pump-assisted convective drier were recommended for drying of onion shreds to maintain the desired quality parameters. Heat pump-assisted convective drying gave better quality product with higher retention of pyruvic and ascorbic acids as compared to hot air drying at $50{ }^{\circ} \mathrm{C}$. Drying at $240 \mathrm{~W}$ and $50{ }^{\circ} \mathrm{C}$ resulted in better quality product as compared to other microwave power levels. Within the experimental range the quality of dehydrated onion was observed to be the best in heat pump-assisted con- 
vective drier at $50{ }^{\circ} \mathrm{C}$ followed by that of microwave-assisted convective drying at $240 \mathrm{~W}$ and $50{ }^{\circ} \mathrm{C}$ and hot air convective drying at $60{ }^{\circ} \mathrm{C}$. The onion shreds pretreated with potassium metabisulphite retained better colour of the dried product irrespective of the drying method. However, in-depth study of these processes is required before commercialization of onion-based food processing industry.

\section{References}

1. Sharma GP, Verma RC, Pathare P. Mathematical modeling of infrared radiation thin layer drying of onion slices. J Food Eng. 2005;71:282-6. http://dx.doi.org/10.1016/j.jfoodeng.2005.02.010

2. Nindo CI, Sun T, Wang SW, Tang J, Powers JR. Evaluation of drying technologies for retention of physical quality and antioxidants in asparagus (Asparagus officinalis L.). Lebensm Wiss Technol. 2003;36:507-16. http://dx.doi.org/10.1016/S0023-6438(03)00046-X

3. Pal US, Khan MK. Heat pump drying of food materials: a critical review. J Food Sci Tech. 2007;44:119-24. http://dx.doi.org/10.1007/s13197-011-0334-z

4. Pal US, Khan MK, Mohanty SN. Heat pump drying of green sweet pepper. Drying Technol. 2008;26:1584-90. http://dx.doi.org/10.1080/07373930802467144

5. Bal LM, Kar A, Satya S, Naik SN. Drying kinetics and effective moisture diffusivity of bamboo shoot slices undergoing microwave drying. Int J Food Sci Tech. 2010;45:2321-8. http://dx.doi.org/10.1111/j.1365-2621.2010.02402.x

6. Swain S, Samuel DVK, Bal LM, Kar A, Sahoo GP. Modeling the microwave assisted drying process of osmotically pretreated red sweet pepper (Capsicum annuum L.). Food Sci Biotechnol. 2012;21:969-78.

http://dx.doi.org/10.1007/s10068-012-0127-9

7. Sahoo NR, Pal US, Dash SK, Khan MK. Drying kinetics and quality aspects during heat pump drying of onion (Allium cepa L.). Int J Food Stud. 2012;1:159-67. http://dx.doi.org/10.7455/ijfs/1.2.2012.a6

8. Lewicki PP, Rajchert DW, Nowark D. Effect of pretreatment on kinetics of convection drying of onion. Drying Technol. 1998;16:83-100.

http://dx.doi.org/10.1080/07373939808917393

9. Tsamo CVP, Bilame AF, Ndjouenkeu R, Nono YJ. Study of material transfer during osmotic dehydration of onion slices and tomato fruits. LWT-Food Sci Technol. 2005;38:495-500. http://dx.doi.org/10.1016/j.lwt.2004.07.015

10. Bolin HR, Petrucci V, Fuller G. Characteristics of mechanically harvested raisins produced by dehydration and by field drying. J Food Sci. 1975;40:1036-8. http://dx.doi.org/10.1111/j.1365-2621.1975.tb02262.x

11. Saravacos GD, Marousis SN, Raouzeos GS. Effect of ethyl oleate on the rate of air-drying of foods. J Food Eng. 1988;7: 263-70.

http://dx.doi.org/10.1016/0260-8774(88)90008-8

12. Doymaz I. Effect of pre-treatments using potassium metabisulphite and alkaline ethyl oleate on the drying kinetics of apricots. Biosyst Eng. 2004;89:281-7. http://dx.doi.org/10.1016/j.biosystemseng.2004.07.009

13. Tunde-Akintunde TY, Afolabi TJ, Akintunde BO. Influence of drying methods on drying of bell pepper (Capsicum annuum). J Food Eng. 2005;68:439-42. http://dx.doi.org/10.1016/j.jfoodeng.2004.06.021

14. Farag RS, Shabana MK, Sallam HA. Biochemical studies on some chemical characteristics of sliced Egyptian onions. J
Food Sci. 1981;46:1394-9.

http://dx.doi.org/10.1111/j.1365-2621.1981.tb04182.x

15. Raj D, Subanna VC, Ahlawat OP, Gupta P, Huddar AG. Effect of pretreatment on the quality characteristics of dehydrated onion rings during storage. J Food Agric Environ. 2006;4:30-3.

16. Tsamo CVP, Bilame AF, Ndjouenkeu R. Air drying behaviour of fresh and osmotically dehydrated onion slices and tomato fruits. Int J Food Prop. 2006;9:877-88. http://dx.doi.org/10.1080/10942910600744098

17. Baroni AF, Hubinger MD. Drying of onion: effects of pretreatments on moisture content. Drying Technol. 1998;16:2083-94. http://dx.doi.org/10.1080/07373939808917513

18. Bebartta JP, Sahoo NR, Dash SK, Panda MK, Pal US. Kinetics modeling and moisture diffusivity of onion slices in fluidized bed drying. J Food Process Preserv. 2014;38:193-9. http://dx.doi.org/10.1111/j.1745-4549.2012.00764.x

19. Pal US, Khan MK. Calculation steps for the design of different components of heat pump dryers under constant drying rate condition. Drying Technol. 2008;26:864-72. http://dx.doi.org/10.1080/07373930802142226

20. Panda MK. Studies on microwave assisted convective dehydration of pine apple [PhD thesis]. Bhubaneswar, Odisha, India: Orissa Univ Agric Technol.; 2006.

21. Viswanathan R, Hulasare R, Jayas DS. Drying characteristics of shredded onion (Allium cepa). J Food Sci Tech. 2003;40: 521-4.

22. Official Methods of Analysis. 11th ed. Washington, DC, USA: Association of Official Analytical Chemists (AOAC); 1984.

23. Ranganna S. Handbook of analysis and quality control for fruit and vegetable products. 2nd ed. New Delhi, India: Tata Mc Graw Hill Publishing Co.; 1986.

24. Schwimmer S, Weston WJ. Onion flavor and odor, enzymatic development of pyruvic acid in onion as a measure of pungency. J Agric Food Chem. 1961;9:301-4. http://dx.doi.org/10.1021/jf60116a018

25. Anthon GE, Barret DM. Modified method for the determination of pyruvic acid with dinitrophenylhydrazine in the assessment of onion pungency. J Sci Food Agric. 2003;83:1210-3. http://dx.doi.org/10.1002/jsfa.1525

26. Bal LM, Kar A, Satya S, Naik SN. Kinetics of color change of bamboo shoot during microwave drying. Int J Food Sci Tech. 2011;46:827-33. http://dx.doi.org/10.1111/j.1365-2621.2011.02553.x

27. Meilgaard M, Civille GV, Carr BT. Sensory evaluation techniques. 3rd ed. Boca Raton, FL, USA: CRC Press; 1999.

28. Maskan M. Microwave/air and microwave finish drying of banana. J Food Eng. 2000;44:71-8. http://dx.doi.org/10.1016/S0260-8774(99)00167-3

29. Maskan M. Drying, shrinkage and rehydration characteristics of kiwifruits during hot air and microwave drying. J Food Eng. 2001;48:177-82.

http://dx.doi.org/10.1016/S0260-8774(00)00155-2

30. Adam E, Mühlbauer W, Esper A, Wolf W, Spiess W. Quality changes of onion (Allium cepa L.) as affected by the drying process. Nahrung. 2000;44:32-7. http://dx.doi.org/10.1002/(SICI)1521-3803(20000101)44:1<32:: AID-FOOD32>3.3.CO;2-6

31. Arslan D, Özcan MNM. Study the effect of sun, oven and microwave drying on quality of onion slices. LWT-Food Sci Technol. 2010;43:1121-7. http://dx.doi.org/10.1016/j.lwt.2010.02.019

32. Kumar HSP, Nagaraju PK, Radhakrishna K, Bawa AS. Effect of dehydration techniques on the quality of onion slices. J Food Sci Tech. 2004;41:397-400. 
33. Lewicki PP, Lazuka WP, Rajchert DW, Nowak D. Effect of mode of drying on storage stability of coloured dried onion. Pol J Food Nutr Sci. 1998;7:701-6.

34. Sarsavadia PN. Development of a solar-assisted dryer and evaluation of energy requirement for the drying of onion. Renew Energ. 2007;32:2529-47.

http://dx.doi.org/10.1016/j.renene.2006.12.019
35. Reyes A, Ceron S, Zuniga R, Moyano P. A comparative study of microwave assisted air drying of potato slices. Biosyst Eng. 2007;98:310-8.

http://dx.doi.org/10.1016/j.biosystemseng.2007.07.006

36. Yongsawatdigul J, Gunasekaran S. Microwave-vacuum drying of cranberries: part II. Quality evaluation. J Food Process Preserv. 1996;20:145-56.

http://dx.doi.org/10.1111/j.1745-4549.1996.tb00851.x 